\title{
PENGARUH WAKTU PENGERINGAN TERHADAP SIFAT OPTIK ZNO NANOPARTIKEL HASIL DARI BIOSINTESIS
}

\author{
Zahra Anjani $^{1, a)}$, Fera Kurniadewi ${ }^{2, a)}$, Iwan Sugihartono ${ }^{1, b)}$ \\ ${ }^{1}$ Program Studi Fisika, FMIPA Universitas Negeri Jakarta, Jl. Rawamangun Muka No. O1, Rawamangun \\ 13220, Indonesia \\ ${ }^{2}$ Program Studi Kimia, FMIPA Universitas Negeri Jakarta, Jl. Rawamangun Muka No. O1, Rawamangun \\ 13220, Indonesia
}

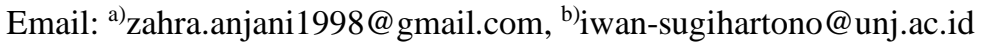

\begin{abstract}
Abstrak
$\mathrm{ZnO}$ Nanopartikel dari berbagai hasil biosintesis akan dilihat sifat optik untuk memberikan konfirmasi pengaruh waktu pengeringan. Pengaruh waktu pengeringan dibandingkan dengan beberapa teknik biosintesis yang mengacu pada 4 penulis, yaitu Vishnupriya (2020) dengan waktu pengeringan 5 hari, Awwad (2020) dengan waktu pengeringan 7 hari, Tura (2018) dengan waktu pengeringan 14 hari, Ezealisiji (2019) dengan waktu pengeringan 21 hari dan pengeringan dilakukan pada temperature ruang. Keempat metode ini menggunakan prekusor yang berbeda namun prosesnya sama. Dikonfirmasi bahwa berdasarkan uji Spektrometer Uv-Vis, puncak absorbansi terjadi pada $360 \mathrm{~nm}$ (5 hari), $369 \mathrm{~nm}$ (7 hari), $365 \mathrm{~nm}$ (14 hari), dan $359 \mathrm{~nm}$ (21 hari). Spectrum Uv-Vis dari ZnO Nanopartikel memiliki absorbansi maksimum yang kuat pada gelombang di bawah $400 \mathrm{~nm}$. Hal ini menjelaskan bahwa tidak adanya factor signifikan dari waktu pengeringan terhadap sifat optik ZnO Nanopartikel dan pola spektrum absorbansi umumnya tergantung pada parameter seperti metode sintesis, suhu, ukuran dan bentuk nanopartikel yang disintesis.
\end{abstract}

Kata Kunci: Nanopartikel ZnO, Biosintesis, Perbedaan Waktu, Absorbansi

\begin{abstract}
$\mathrm{ZnO}$ nanoparticles from various biosynthetic results will be seen by optical character to confirm the effect of drying time. The effect of drying time is compared with some biosynthetic techniques which refer to 4 authors, Vishnupriya (2020) with a drying time of 5 days, Awwad (2020) with a drying time of 7 days, Tura (2018) with a drying time of 14 days, Ezealisiji (2019) with drying time of 21 days and drying is done at room temperature. These four methods use different precursors but the process is the same. It is confirmed that based on the Uv-Vis Spectrometer test, the peak absorbance occurred at 360 $\mathrm{nm}$ (5 days), $369 \mathrm{~nm}$ (7 days), $365 \mathrm{~nm}$ (14 days), and $359 \mathrm{~nm}$ (21 days). The Uv-Vis Spectrum of $\mathrm{ZnO}$ Nanoparticles has a strong maximum absorbance in waves below $400 \mathrm{~nm}$. This is explains that there is no significant factor of drying time on the optical character of $\mathrm{ZnO}$ nanoparticles and the absorbance spectrum pattern generally depends on parameters such as the synthesis method, temperature, size and shape of the synthesized nanoparticles.
\end{abstract}

Keywords: ZnO Nanopartiles, Biosynthetic, Drying Time, Absorbance 


\section{PENDAHULUAN}

Pada saat ini, pengembangan nanoteknologi terus dilakukan oleh peneliti. Pengembangan nanoteknologi tidak terlepas dari riset mengenai material nano, salah satunya adalah nanopartikel. Nanopartikel merupakan partikel padat yang memiliki ukuran kurang dari 100 nanometer [1]. Nanopartikel memiliki keunikan sifat fisika, sifat kimia, dan sifat toksisitas tergantung pada perbedaan ukuran, distribusi, dan morfologi nanopartikel [2]. Penelitian nanopartikel logam oksida yang menarik dan saat ini banyak dilakukan adalah Seng Oksida atau ZnO (Zinc oxide). Nanopartikel $\mathrm{ZnO}$ telah diaplikasikan pada berbagai macam bidang, seperti bidang industri, pangan, kesehatan, biomedis, lingkungan, dan pertanian [2] (Yadav, Bandopadhyay and Saha 2015). ZnO terbentuk dari unsur-unsur yang melimpah dan tidak beracun. $\mathrm{ZnO}$ memiliki memiliki stabilitas kimia dan termal yang tinggi, dengan energi celah pita yang besar yaitu 3,37 eV dengan energi pengikat exciton sebesar $60 \mathrm{MeV}$ [3]. ZnO memperlihatkan sifat-sifat optik dan kelistrikan yang baik serta memiliki sejumlah potensi aplikasi dalam bidang elektronik, optoelektronik, dan sensor. $\mathrm{ZnO}$ sangat potensial sebagai elektroda transparan dalam teknologi fotovoltaik, piranti elektroluminisens, dan material untuk piranti pemancar ultraviolet [4].

Sebelumnya sintesis nanopartikel dilakukan dengan dua metode, yaitu metode fisika dan metode fisika. Namun, kedua metode tersebut memiliki kelemahan, yaitu memerlukan peralatan mahal, dilakukan dengan suhu tinggi, memerlukan ruang yang besar untuk pengaturan mesin, menggunakan bahan-bahan kimia beracun yang limbahnya berpotensi menjadi polutan bagi lingkungan. Saat ini, metode biosintesis atau green synthesis sedang dikembangkan sebagai alternatif pembuatan nanopartikel yang bersifat ramah lingkungan, dengan menghasilkan karakteristik nanopartikel yang baik [5]. Dalam proses biosintesis nanopartikel tersebut, organisme yang memiliki peran adalah cyanobakteria, bakteria, yeast, fungi, diatoms, mikroalga, makroalga, dan ekstrak tanaman. Biosintesis nanopartikel $\mathrm{ZnO}$ dengan ekstrak tanaman sudah banyak dilakukan oleh para peneliti dan membuktikan biosintesis merupakan cara efisien untuk sintesis nanopartikel [6].

\section{METODOLOGI}

\section{Buah Hylocereus undatus}

- Buah Hylocereus undatus dibersihkan dengan distilled water dan dikeringkan selama 5 hari pada temperature ruang. Kemudian buah dihancurkan sampai menjadi bubuk menggunakan blender.

- $20 \mathrm{~g}$ bubuk buah Hylocereus undatus ditambahkan ke dalam $100 \mathrm{ml}$ distilled water dan dipanaskan sampai menjadi ekstrak. Setelah itu, ekstrak disentrifugasi pada $5000 \mathrm{rpm}$ selama 5 menit dan simpan untuk digunakan.

- ZnO Nanopartikel disintesis dengan $50 \mathrm{ml}$ Zinc chloride ditambahkan ke dalam ekstrak buah Hylocereus undatus $50 \mathrm{ml}$ kemudian diaduk selama semalam dengan magnetic stirrer. Setelah itu, campuran akan berganti warna, kemudian disentrifugasi pada $8000 \mathrm{rpm}$ selama 15 menit dan dikeringkan dengan hot air oven pada suhu $80^{\circ} \mathrm{C}$ selama 2 jam.

\section{Buah Ailanthus altissima}

- Buah Ailantus altissima dibersihkan dengan air beberapa kali dengan air dan dikeringkan selama 7 hari pada temperature ruang. Kemudian buah dihancurkan sampai menjadi bubuk menggunakan 350 mesh sieve.

- $10 \mathrm{~g}$ bubuk buah Ailantus altissima ditambahkan ke dalam $1 \mathrm{~L}$ de-ionized water dan dipanaskan pada temperatur $80^{\circ} \mathrm{C}$ selama 10 menit sampai ekstrak berwarna merah, kemudian dibiarkan dingin pada temperatur ruang. Setelah itu, ekstrak disaring menggunakan kertas saring Whatman dan simpan untuk digunakan. 
- ZnO Nanopartikel disintesis dengan $10 \mathrm{~g}$ Zinc nitrate hexahydrate yang dilarutkan ke dalam $200 \mathrm{ml}$ de-ionized water kemudian distirrer menggunakan magnetic bar pada temperature ruangSetelah itu, ekstrak bunga Ailantus altissima dimasukkan secara perlahan ke dalam larutan Zinc nitrate hexahydrate sampai berwarna coklat kemerahan. Campuran dibiarkan semalam dan saring kembali untuk mendapatkan partikel tersuspensi, kemudian dikeringkan dalam oven pada temperature $80^{\circ} \mathrm{C}$ selama 4 jam.

\section{Umbi Coccinia abyssinica}

- Umbi Coccinia abyssinica dibersihkan beberapa kali dengan air dan dikeringkan selama 14 hari pada temperature ruang. Kemudian umbi dihancurkan sampai menjadi bubuk menggunakan blender.

- $5 \mathrm{mg}$ bubuk umbi Coccinia abyssinica ditambahkan ke dalam $100 \mathrm{ml}$ double distilled water dan dipanaskan selama 60 menit. Ekstrak didinginkan pada temperature ruang kemudian disaring, ekstrak yang sudah disaring sebanyak $50 \mathrm{ml}$ distirrer dengan pengadukan konstan pada temperature $60-80^{\circ} \mathrm{C}$.

- ZnO Nanopartikel disintesis dengan $100 \mathrm{ml}$ larutan Zinc acetate dehydrate 0,1 M yang ditambahkan ke dalam ekstrak umbi Coccinia abyssinica kemudian dipanaskan pada temperature $60-80^{\circ} \mathrm{C}$ dengan pengadukan konstan selama 2 jam. Kemudian ditambahkan larutan $0.1 \mathrm{M} \mathrm{NaOH}$ agar $\mathrm{pH}$ menjadi 11 dan terbentuk endapan. ZnO Nanopartikel dibersihkan dengan double distilled water dan dikeringkan. $\mathrm{ZnO}$ Nanopartikel disimpan untuk digunakan.

\section{Daun Solaum torvum rimbamg}

- Daun Solaum torvum dibersihkan sebanyak tiga kali dengan tap water dan de-ionized water, dikeringkan selama 21 haripada temperature ruang. Kemudian daun dihancurkan sampai menjadi bubuk.

- Bubuk daun direbus dengan analyticalgrade water selama 45 menit pada suhu $100{ }^{\circ} \mathrm{C}$ kemudian disaring untuk memisahkan larutan dengan endapan menggunakan corong kaca sinter $0,45-\mu \mathrm{m}$ dan ekstrak yang dihasilkan disimpan di refrigerator pada suhu $4{ }^{\circ} \mathrm{C}$ sampai digunakan.

- ZnO Nanopartikel disintesis dengan $200 \mathrm{ml}$ larutan Zinc nitrate $(1,5 \mathrm{mM})$ yang dimasukkan ke dalam $20 \mathrm{ml}$ ekstrak daun Solaum torvum kemudian ditambahkan $10 \mathrm{ml} \mathrm{NaOH}$. Kemudian campuran diaduk dengan kecepatan konstan pada incubator suhu $60^{\circ} \mathrm{C}$. ZnO NPs berwarna putih dihasilkan setelah 24 jam. ZnO NPs disentrifugasi kemudian dibersihkan dengan double distillated water dan etanol, dikeringkan, disimpan pada botol sampel sampai digunakan.

\section{HASIL DAN PEMBAHASAN}

Pada penelitian Sishnupriya dkk (2020) yang mensintesis ZnO Nanopartikel menggunakan ekstrak buah Hylocereus undatus dengan waktu pengeringan selama 5 hari pada temperature ruang. HSishnupriya dkk melaporkan bahwa spektrum Uv-Vis menunjukkan sintesis ZnO Nanopartikel mengalami pergeseran puncak absorbansi pada $360 \mathrm{~nm}$. Telah dilaporkan sebelumnya bahwa absorbansi pada $360 \mathrm{~nm}$ menunjukkan karakteristik ZnO Nanopartikel [7]. Penelitian serupa juga dilakukan spectrum Uv-Vis dari ZnO Nanopartikel memiliki daya serap maksimum yang kuat pada gelombang di bawah $400 \mathrm{~nm}$ [8]. 
Awwad dkk (2020) mensintesis ZnO Nanopartikel menggunakan ekstrak buah Ailantus altissima dengan waktu pengeringan selama 7 hari pada temperature ruang. Awwad dkk melaporkan bahwa $\mathrm{ZnO}$ Nanopartikel yang semula pucat berubah menjadi coklat selama reaksi dan perubahan warna dari coklat menjadi putih selama 2 jam pemanasan menggunakan muffle furnace pada suhu $450^{\circ} \mathrm{C}$. Spektrum Uv-Vis menunjukkan bahwa puncak absorbansi berada diantara gelombang 360-369 nm. Hal ini mengkonfirmasi adanya pembentukan ZnO Nanopartikel.

Tura dkk (2018) mensintesis ZnO Nanopartikel menggunakan ekstrak umbi Coccinia abyssinica dengan waktu pengeringan selama 14 hari pada temperature ruang. Tura dkk melaporkan bahwa spectrum Uv-Vis menunjukkan ZnO Nanopartikel mengalami absorbansi maksimum pada $365 \mathrm{~nm}$, dan sesuai dengan penelitian yang sudah dilakukan sebelumnya [9]. Absorbansi maksimum untuk $\mathrm{ZnO}$ Nanopartikel biasanya terjadi pada $380 \mathrm{~nm}$ [10]. Absorbansi maksimum ini mengkonfirmasi adanya pembentukan $\mathrm{ZnO}$ Nanopartikel [11].

Ezealisiji dkk (2019) mensintesis ZnO Nanopartikel menggunakan ekstrak daun Solanum torvum. Campuran ekstrak daun Solanum torvum dan Zinc nitrate dalam larutan menghasilkan perubahan warna yang jelas setelah 24 jam inkubasi dari coklat kekuningan menjadi putih. Perubahan warna yang diamati mengkonfirmasi adanya pembentukan $\mathrm{ZnO}$ Nanopartikel. Spektrum UV-Vis menunjukkan bahwa puncak absorbansi maksimum terjadi pada $359 \mathrm{~nm}$ dan merupakan ciri khas untuk $\mathrm{ZnO}$ Nanopartikel. Bentuk nanopartikel yang disintesis sesuai dengan teori Mei, yang menyatakan bahwa sintesis nanopartikel akan berbentuk bulat jika puncak absorbansi tunggal diamati dalam spektrum UV-Vis [12].

\section{SIMPULAN}

Spektrum Uv-Vis menunjukan bahwa puncak absorbansi terjadi pada $360 \mathrm{~nm}$ untuk waktu pengeringan 5 hari, $369 \mathrm{~nm}$ untuk waktu 7 hari, $365 \mathrm{~nm}$ untuk waktu 14 hari, dan $359 \mathrm{~nm}$ untuk waktu 21 hari. Hal ini sesuai dengan penelitian yang telah dilakukan sebelumnya bahwa spektrum Uv-Vis dari ZnO Nanopartikel memiliki absorbansi maksimum yang kuat pada gelombang di bawah $400 \mathrm{~nm}$. Hal ini menjelaskan bahwa tidak adanya factor signifikan dari waktu pengeringan terhadap sifat optik ZnO Nanopartikel dan pola spektrum absorbansi umumnya tergantung pada parameter seperti metode sintesis, suhu, ukuran dan bentuk Nanopartikel yang disintesis.

\section{UCAPAN TERIMAKASIH}

Terima kasih kepada pihak pemberi dana penelitian, kepada lembaga/orang yang membantu penelitian, kepada orang yang membantu dalam diskusi. Ucapan terima kasih kepada Dr. Iwan Sugihartono, M. Si dan Dr. Fera Kurniadewi, M.Si yang telah membimbing dan membantu dalam proses pembuatan paper ini. Semoga review paper ini berguna dan bermanfaat bagi pembaca. Mohon maaf apabila terdapat kesalahan dan kekurangan dalam penulisan review ini.

\section{REFERENSI}

[1] A. Albanese, P. S. Tang and W. C. W Chan, "The Effect of Nanoparticle Size, Shape, and Surface Chemistry on Biological Systems," Annual Review of Biomedical Engineering, pp. $1-16,2012$.

[2] R. Yadav, M. Bandopadhyay and A. Saha, "Synthesis, Characterisation, Antibacterial and Cytotoxic Assay of Zinc Oxide (ZnO) Nanoparticles," pp. 1-10, 2015.

[3] J. Tamil Illakkiya et al., "Characterization of $\mathrm{ZnO}$ Nanoparticles synthesized by wet chemical method," International Journal of ChemTech Research, pp. 974-4290, 2014.

[4] Abdullah et al., "Review : Sintesis Nanomaterial," Jurnal Nanosains \& Nanoteknologi, p. 33, 2008. 
[5] R. Nurbayasari, N. Saridewi and Shofwatunnisa, "Biosynthesis and Characterizationof ZnO Nanoparticles with Extract of Green Seaweed Caulerpa sp," Jurnal Perikanan Universitas Gadjah Mada, pp. 17-26, 2017.

[6] G. Rajakumar et al., "Green approach for synthesis of zinc oxide nanoparticles from Andrographis paniculata leaf extract and evaluation of their antioxidant, anti-diabetic, and anti-inflammatory activities," Bioprocess Biosyst Eng, vol. 41, pp. 21-30, 2018.

[7] N. Bala et al., "Green synthesis of zinc oxide nanoparticles using Hibiscus subdariffa leaf extract: effect of temperature on synthesis, anti-bacterial activity and anti-diabetic activity," RSC Adv, pp. 4993-5003, 2015.

[8] Kumar et al., "Synthesis, characterization and optical properties of zinc oxide nanoparticles," Int. Nano Lett, p. 30, 2015.

[9] V. Nayagam, M. Gabriel and K Palanisamy, "Green synthesis of silver nanoparticles mediated by Coccinia grandis and Phyllanthus emblica: a comparative comprehension," pp. 205-219, 2018.

[10] S. Senthilkumar and T. Sivakumar, "Green tea (Camellia sinensis) mediated synthesis of zinc oxide $(\mathrm{ZnO})$ nanoparticles and studies on their antimicrobial activities," Int, J. Pharm, pp. 461-465, 2014.

[11] P. Jamdagni, P. Khatri and J. S. Rana, "Green synthesis of zinc oxide nanoparticles using flower extract of Nyctanthes arbor-tristis and their antifungal activity," 2016.

[12] S. Elias, G. Elham and N. Kazem, "Size-controlled and optical properties of monodispersed silver nanoparticles synthesized by the radiolytic reduction method," pp. 7880-7896, 2013. 
